DOI: $10.2478 / \mathrm{v} 10129-011-0037-7$

Slobodan Tomasović ${ }^{1}$, Branko Palaveršić ${ }^{1}$, Ivica Ikić$^{1}$, Rade Mlinar ${ }^{1}$,

Hrvoje Šarčević ${ }^{2}$, Katarina Jukić ${ }^{1}$, Tomislav Ivanušić ${ }^{1}$

${ }^{1} \mathrm{Bc}$ Institute for Breeding and Production of Field Crops d.d. Zagreb, Rugvica, Dugoselska 7, 10370 Dugo Selo, Croatia (e-mail: bc-botinec@bc-institut.hr), ${ }^{2}$ Faculty of Agronomy of the Zagreb University, Svetošimunska 25, 10000 Zagreb, Croatia

\title{
LATEST RESULTS IN BREEDING WINTER WHEAT FOR RESISTANCE TO FUSARIUM HEAD BLIGHT IN THE ZAGREB BC INSTITUTE
}

\begin{abstract}
Fusarium head blight (Fusarium graminearum Schw.) is one of the most dangerous fungal diseases in wheat production decreasing grain yield up to $50 \%$ or more what depends on both environmental factors and genotype. Testing of inoculated artificially new Bc winter wheat lines for their resistance to FHB was the objective of the study.

In 2008 and 2009 two and five lines of tested 12 new ones respectively were shown to be more resistant than Sana cultivar used as a standard. Majority of the winter wheat lines exceeded level of resistance standing out by Bc 7 and Bc 1 and Bc Lira variety as the highest yielding variety was registered by CCVR in 2009 .
\end{abstract}

Key words: Bc lines, Fusarium graminearum, FHB, resistance, testing, winter wheat

\section{INTRODUCTION}

Fusarium head blight (Fusarium graminearum Schw.) is one of the most dangerous fungal diseases in wheat production because it can cause considerable reductions in grain yield up to $50 \%$ or more. Yield reductions depend both on environmental factors and the genotype (Korić, Tomasović, 1989; Tomasović, 1981; Tomasović et al., 1993). Breeding for resistance to head blight relies on determining the most effective methods of artificial inoculation, reliable scoring, detection of sources of resistance and their incorporation into the high-yielding genotypes suited to local growing conditions and with favourable agronomic properties.

Communicated by Edward Arseniuk 
The objective of the present study is to test the new $\mathrm{Bc}$ winter wheat lines for resistance to fusarium head blight under conditions of artificial inoculation with Fusarium graminearum Schw., which will then be used in breeding process for development of new lines, later wheat varieties with high resistance to head fusarium.

\section{MATERIALS AND METHODS}

Resistance degree of wheat lines to head blight is tested continuously in field trials in Bc Institute's Department of Cereal Crops in Botinec under conditions of artificial inoculation. The aim is to test as many breeding lines as possible. Thus, in 2008 and 2009 , field trials were conducted under artificial and natural infections in 4 replications following a randomized block design. Basic plot size was $1,20 \mathrm{~m}^{2}(1,20 \mathrm{~m} \mathrm{x}$ $0,25 \mathrm{~m} \mathrm{x} 4$ rows). In both years, 16 genotypes were tested for resistance to fusarium head blight and yield capacity. Three standards for resistance were included in testing, i.e. Roazon, (D 48x42x6) 2 and Poncheau, and a standard for yield capacity - Sana. Modified Bilay's liquid substrate was used for inoculum production (Reid et al, 1996). The four most aggressive isolates of Fusarium graminearum Schw. were used, tested by means of the Mesterhazy method (1984). Artificial inoculation was made by the "spray-method", with a concentration of $5 \times 10^{5}$ of spores $/ \mathrm{ml}$. Inoculation was made by hand with a 5-1 sprayer. First artificial inoculation was carried out at anthesis, i.e. when $50 \%$ or more spikes flowered. The inoculation was repeated 3 times at 4-5 days intervals. Assessment of fusarium head blight attack was made 14 days following the second inoculation. The second and the third ratings were taken at late milk and early wax stage at 5-8 day intervals when the infection was clearly visible. The visual rating index (VRI \%) was made by using a formula (VRI \%) = incidence $\mathrm{x}$ severity $/ 100$ (Gilbert, Morgan, 2000). Infection severity was rated by using the scale $(0 \%, 5 \%, 25 \%, 75 \%$ and $100 \%)$ of spikes infected (Tomasović, 1987; Palaveršić, Tomasović, 2005). VRI indices were transformed to arc sin $\sqrt{\%}$ after Gomez-Gomez, 1984. Analysis of variance and t-test were made. Data on resistance were statistically processed after Kruger and Weiler, 1975 and genotypes were classified into 5 groups: -- very susceptible, - susceptible, 0 moderately susceptible, + moderately resistant and + resistant. Average value of resistance was obtained based on 3 fusarium attack assessments.

\section{RESULTS AND DISCUSSION}

In breeding for development of high-yielding wheat varieties resistant to head blight, one of the most important factors for a successful work is application of artificial inoculation. For this purpose, from the genetic point of view, a continuous exchange of sources of resistance is conducted with the breeders from all over the world. These sources are then tested under local conditions and strict criteria of artifi- 
cial inoculation. A small number of sources with favourable agronomic traits was screened (Tomasović et al, 2005).

In 2008 and 2009, 16 winter wheat genotypes were tested for resistance to fusarium head blight under artificial and natural infections. In both years, 12 new genotypes were tested. In the first year of testing two lines were more yielding than the check Sana, while in the second year 5 genotypes were considerably more yielding than the check (Table 1).

Table 1

Results of testing 16 wheat materials for yield, Botinec 2008, 2009.

\begin{tabular}{lccc}
\hline Genotype & \multicolumn{3}{c}{ Grain yield (kg/ha) } \\
\cline { 2 - 4 } Bc 7 & 2008. & 2009. & Mean \\
\hline Bc 10 & 9862.5 & $9383.3 *$ & 9622.9 \\
Bc 4 & 10416.7 & $8133.3 *$ & 9275.0 \\
Bc 11 & 10137.5 & $7862.5 *$ & 9000.0 \\
Bc Lira & 10683.3 & 7012.5 & 8847.9 \\
Sana & 9625.0 & $8066.7 *$ & 8845.9 \\
Bc 3 & 10379.2 & 6983.3 & 8681.3 \\
Bc 2 & 9683.3 & $7625.0 *$ & 8654.2 \\
Bc 1 & 9725.0 & 7112.5 & 8418.8 \\
Bc 6 & 9612.5 & 7195.8 & 8404.2 \\
Bc 9 & 9958.3 & 6666.7 & 8312.5 \\
(D 48 x 42 x 6) 2 & 9191.7 & 7212.5 & 8202.1 \\
Bc 5 & 9016.7 & 6708.3 & 7862.5 \\
Roazon & 7995.8 & 6866.7 & 7431.3 \\
Bc 12 & 7866.7 & 6875.0 & 7370.9 \\
Poncheau & 7862.5 & 6579.2 & 7220.9 \\
Mean & 4929.2 & 5979.2 & 5454.2 \\
LSD (0,05) & 9184.1 & 7266.4 & 8225.3 \\
\hline & 437.8 & 437.8 & \\
\hline & & & \\
\hline & & & \\
\hline
\end{tabular}

Significant differences in resistance to fusarium head blight were obtained among the tested genotypes (Table 2). Based on a visual rating index (VRI \%), the highest level of resistance to fusarium head blight was achieved by the genotype Bc Lira $(9,16 \%)$ and the lines Bc 1 and $\mathrm{Bc} 7$ $(12,23 \%$ and $14,38 \%$ respectively). Average resistance level was $<x>=$ $26,65 \%$. Likewise, the mentioned genotypes achieved high grain yields. 
The highest yield was obtained by the line Bc $7(9622,9 \mathrm{~kg} / \mathrm{ha})$, then $\mathrm{Bc}$ Lira and $\mathrm{Bc} 1(8845,9 \mathrm{~kg} / \mathrm{ha}$ and $8404,2 \mathrm{~kg} / \mathrm{ha}$ respectively). Average grain yield was $\angle \mathrm{x}>=8225,3 \mathrm{~kg} / \mathrm{ha}$, and the one achieved by the check Sana was $8681,3 \mathrm{~kg} / \mathrm{ha}$. In addition to high yield, Bc Lira expressed the highest resistance level to fusarium head blight. Standards for resistance, Poncheau, Roazon and (D $48 \times 42 \times 6)_{2}$ proved their high level of resistance, but had low grain yields.

Table 2

Results of testing 16 wheat materials for resistance to fusarium head blight, Botinec 2008, 2009

\begin{tabular}{|c|c|c|c|}
\hline \multirow{2}{*}{ Genotype } & \multicolumn{3}{|c|}{ FHB (VRI\%) } \\
\hline & 2008 & 2009 & Mean \\
\hline $\mathrm{Bc} 7$ & $3.85++$ & 24.90 & 14.38 \\
\hline $\mathrm{Bc} 10$ & $31.46-$ & $79.40--$ & 55.43 \\
\hline $\mathrm{Bc} 4$ & $14.44+$ & 33.60 & 24.02 \\
\hline $\mathrm{Bc} 11$ & $14.27+$ & 25.80 & 20.04 \\
\hline Bc Lira & $3.71++$ & $14.60+$ & 9.16 \\
\hline Sana & $27.50-$ & 33.40 & 30.45 \\
\hline $\mathrm{Bc} 3$ & $35.62--$ & $58.20--$ & 46.91 \\
\hline $\mathrm{Bc} 2$ & $30.31-$ & 56.90 -- & 43.61 \\
\hline $\mathrm{Bc} 1$ & $8.25+$ & $16.20+$ & 12.23 \\
\hline $\mathrm{Bc} 6$ & 18.44 & $43.30-$ & 30.87 \\
\hline $\mathrm{Bc} 9$ & $33.12-$ & $44.70-$ & 38.91 \\
\hline$(\mathrm{D} 48 \times 42 \times 6)_{2}$ & $6.75++$ & 34.20 & 20.48 \\
\hline Bc 5 & $37.50--$ & $39.60-$ & 38.55 \\
\hline Roazon & $14.89+$ & 26.00 & 20.45 \\
\hline $\mathrm{Bc} 12$ & $13.77+$ & $24.30+$ & 19.04 \\
\hline Poncheau & $0.58++$ & $3.30++$ & 1.94 \\
\hline Mean & 18.40 & 34.90 & 26.65 \\
\hline
\end{tabular}




\section{CONCLUSION}

1. Breeding winter wheat for resistance to fusarium head blight is a permanent process the aim of which is to develop our own material with as good level of resistance to this disease as possible, high yielding capacity and stability in production.

2. Majority of the winter wheat lines tested expressed high resistance level among which $\mathrm{Bc} 7$ and $\mathrm{Bc} 1$ stand out. The variety Bc Lira achieved the highest level of resistance to fusarium head blight during 2008 and 2009. Also, it produced high grain yield. Bc Lira was registered by the Croatian Committee for Variety Registration in 2009 as a new winter wheat variety. Application of artificial infection has proved successful in our winter wheat breeding program.

\section{REFERENCES}

Gilbert, J., Morgan, K. (2000): Field - based rating of spring wheat infected with Fusarium graminearum, cause of Fusarium head blight. $6^{\text {th }}$ European Seminar on Fusarium - Mycotoxins, Taxonomy and Pathogenicity, Berlin. Book of Abstracts: 73.

Gomez, K. A., Gomez, A. A. (1984): Statistical procedures for agricultural research, John Willey.

Korić, B., Tomasović, S. (1989): Utjecaj gljive Fusarium graminearum Schw.na sniženje uroda pšenice. Agronomski glasnik, 3: $49-53$.

Kruger, W., Weiler, N. (1975): Über die Anfälligheit der Maishybriden gegen Wurzelfaule. Z. Acker - und Pflazenbau, 141: $205-210$.

Mesterhazy, A. (1984): A laboratory method to predict pathogenicity of Fusarium graminearum in field and resistance of wheat to scab. Acta Phytopathologica Academiae Scientiarum Hungaricae, 19: 205-218.

Palaveršić, B., Tomasović, S. (2005): Usporedba tri načina ocjenjivanja fuzarijske paleži klasa pšenice. Zbornik radova - 40 znanstveni skup hrvatskih agronoma s međunarodnim sudjelovanjem - Kovačević, Vlado, Jovanovac, Sonja ( ur. ), Opatija, Croatia, 2005: 221-222.

Reid, L. M., Hamilton, R. I., Mather, D. E. (1996): Screening maize for resistance to Gibberella Ear Rot. Technical Bulletin 1996 - 5 E. Agriculture and Agri - Food Canada.

Tomasović, S. (1981): Breeding of wheat for resistance to Fusarium diseases, especially to Fusarium graminearum and creating a model for inheritance of resistance in new wheat cultivars. Genetika, 13, 2: $177-187$

Tomasović, S. (1987): Skala za ocjenjivanje napada fuzarijske paleži klasa pšenice ( Fusarium graminearum Schw. ). Glasnik zaštite bilja 6: $228-230$.

Tomasović, S., Vlahović, V., Sesar, B. (1993): Važnost oplemenjivanja ozime pšenice na otpornost na fuzarijsku palež klasa ( Fusarium graminearum Schw. i Fusarium moniliforme var. subglutinans ). Sjemenarstvo 10: 3 - 24 .

Tomasović, S., Palaveršić, B., Ikić, I. (2005): Study of wheat lines resistance to Fusarium head blight. Cereal Research Communications, Vol. 33, No. 2-3: 583 - 588. 